\title{
Slum upgrading and inclusive municipal governance in Harare, Zimbabwe: New perspectives for the urban poor
}

\author{
Davison Muchadenyika \\ University of the Western Cape, Institute for Social Development, Private Bag X17, Bellville 7535, South Africa
}

\section{A R T I C L E I N F O}

\section{Article history:}

Received 16 August 2014

Received in revised form

26 January 2015

Accepted 12 March 2015

Available online 20 March 2015

\section{Keywords:}

Urban poor

Gradual institutional change

Citizen participation

Slum upgrading

Housing

Inclusive municipal governance

Urban services

Harare

Zimbabwe

\begin{abstract}
A B S T R A C T
The story of the urban poor in Harare and Zimbabwean cities in general is a story of evictions, fear and misery. In May 2005, at the behest of the Government of Zimbabwe the infamous Operation Restore Order, a house demolition campaign left more than 700 thousand people homeless. Nearly a decade later, there are increased opportunities for improvement and change in the lives of the urban poor in Harare, Zimbabwe's capital city. The purpose of the paper is to present how the Harare Slum Upgrading Programme is creating and strengthening municipal and community partnerships to tackle city challenges in an inclusive manner. This research indicates the housing struggles of the urban poor and the emerging City-community engagement in urban services provision (water, sanitation, tenure security and roads) and changing municipal attitudes towards the urban poor. In particular, the article presents participatory urban planning and development, slum upgrading institutional structure, profiling and enumeration, and slum upgrading impacts (resilience of the urban poor, living in slums without fear, expansive pool of beneficiaries, review of planning regulations and land ownership) as major issues promoting inclusive municipal governance. Inclusivity is implemented through incremental development, which is allowing people to settle on land first and access municipal services gradually over time. Two main factors explain such positive steps towards inclusive governance in Harare. First are indications of gradual institutional change in which the City of Harare's governance culture is changing through 'opening up' and embracing the urban poor. Second, over the years, the urban poor have built a strong and vibrant alliance which is acting as a medium of participation in City governance. The paper concludes that slum upgrading sustainability at city-wide level requires active City participation and institutionalisation as opposed to a project based approach. Lastly, addressing concerns of the urban poor is susceptible to political contestations, requiring strong impartiality to counter such forces.
\end{abstract}

(c) 2015 Elsevier Ltd. All rights reserved.

\section{Introduction}

That there are considerable housing challenges in Zimbabwe's major cities is not in doubt. Zimbabwe's housing backlog is estimated to be at least 1 million units, though there is no comprehensive assessment to substantiate this figure (GoZ, 2012). The City of Harare's estimated housing backlog stands in excess of 500,000. Meanwhile, Zimbabwe's urbanisation rate has increased from $10.64 \%$ in 1950 to $38.25 \%$ in 2010 and is expected to increase to $64.35 \%$ by 2050 (UNHABITAT, 2010). Increasing urbanisation is putting a strain on housing, urban services and infrastructure. Admittedly, this is happening against a backdrop of sluggish economic growth rendering most local authorities to shelve low-cost

E-mail address: muchadenyikad@gmail.com. housing targeted at the urban poor. By definition, the urban poor are urban residents who live in poverty (Kamete, 2002); with little or no access to land and basic infrastructure and social services.

Within the context of rapid urbanisation, socio-economic and political crisis; post-2000 Zimbabwe realised significant changes to housing delivery. These changes challenged the conventional urban planning and housing delivery methods; as Zimbabwe's urban planning standards have been widely criticised as stifling housing delivery. Town planning standards have been castigated as 'very high, very elaborate, rigid and not amenable to physical and climatic conditions', irresponsive to end users with planners criticised for planning for themselves (GoZ, 2009). Further, the urban planning system is inherently technocratic, robustly bureaucratised, and manifestly modernist and has not responded adequately to changes over time (Kamete, 2006). The Government of Zimbabwe adopted planning related changes which focused mainly on 
reducing stand sizes. However, an Urban LandMark study found out that 'in general the adjustments to planning standards are still inadequate' (Marongwe, Chatiza, \& Mukoto, 2011: 47). Reducing planning standards was deemed piecemeal, hence the continued clash between planning authorities and the urban poor over planning procedures in housing delivery.

One of the key challenges of the 21st century is the construction of new relationships between citizens and governments (in particular local government) (Gaventa, 2001; Mitlin, 2004: 3). Governance refers to 'the formation and stewardship of formal and informal rules that regulate the public realm, the arena in which state as well as economic and societal actors interact to make decisions' (Hyden, Court, \& Mease, 2004). Governance arrangements decide the distribution questions of who gets what, when, and how. The debate on governance and democracy is extended from governance at the level of policy making and implementation to governance at the level of politics and decision-making (Hyden et al., 2004; Sorensen \& Torfing, 2007). Other scholars argue that participation, citizenship and development is not only about inclusion and voice in projects, programs and policies, but also about politics, power and influence (Gaventa, 2007; Hyden et al., 2004). This view emphasises on participation that changes and reconfigures the balance of power and politics.

Whilst others (for instance Hendricks, 2010) have used a governance networks approach to explain how the poor people can influence service delivery, this article uses the framework of gradual institutional change (Van der Heijden, 2013a, 2013b; Mahoney \& Thelen, 2010a, 2010b); and citizen participation and civil society engagement as important drivers of inclusive governance (Mitlin, 2004; Thompson \& Tapscott, 2010). Such a framework provides proximate explanation of the situation in Harare City. Harare provides a unique and changing way in as far as how the city is engaging and incorporating the urban poor's concerns in urban governance and development. Further, Zimbabwe has gone through an unprecedented economic and political crisis which has made it difficult for cities to provide urban services. On the other hand, the decade-interval urbanisation growth rate is increasing at a rate of between 5 and 6\% (UNHABITAT, 2010); providing a fertile ground for change in urban governance approaches. Contextually, the Inclusive Government (2009-13) composed of the opposition Movement for Democratic Change (MDC) and the Zimbabwe African National Union Patriotic Front (Zanu-PF) provided a new political and governance culture with new institutions and rules ushered in by the new Constitution. The MDC is a political party born out of civil society coalitions and hence it prioritised working with civil society organisations in promoting citizen participation and citizen-centred governance. This context provided impetus for change in city governance in Harare.

The following section presents the framework of inclusive governance approaches, and a short literature overview of slum upgrading. After that, the paper provides a brief overview of attempts at housing the urban poor in Zimbabwe before describing housing institutions, actors, and their roles. Thereafter, the article gives a brief overview of slum upgrading in Harare followed by an explanation on the research methodology, and a presentation, and discussion of the research findings. Finally the paper concludes by summarising key findings, and policy recommendations.

\subsection{Inclusive governance approaches and slum upgrading}

Inclusive and participatory governance contributes to poverty reduction through focusing on the needs of the poor (Mitlin, 2004). The currency of inclusive governance is driven by a number of factors chief among them civil society, government policies like decentralisation, the desire to pursue legitimate politics among others. By definition inclusive governance emphasises on governance arrangements that promote the inclusion of the people in particular the poor and marginalised. It emphasises the need to introduce mechanisms to encourage the involvement of those who do not find it easy to participate in state structures and processes because they are generally far removed from their own cultures and practices (Mitlin, 2004: 4). In particular, inclusive governance is anchored on new structures and processes of engagement which are friendly, and specific to the needs of the poor. Smith (2004) points to the potency of processes leading to inclusive governance and the role of weaker groups in negotiating, and fighting for transfer of power in urban management.

\subsection{Gradual institutional change}

The inclusion of the urban poor in city governance is subject to the configuration of existing governance institutions. Over time, institutions change. Such a change can be incremental or a result of exogenous shocks (Pierson, 2004). Sudden shifts in society and government for instance war and financial crisis trigger institutional change. On the other hand stickiness of institutional cultures, the bounded rationality of policy makers and vested interests make it difficult to change institutions (Van der Heijden, 2013a). From an incrementalist perspective, institutions change but gradually over time (Campbell, 2009; Van der Heijden, 2013a). This change takes place between two opposing forces; other actors are pro-change whilst others are struggling to maintain the status quo.

Gradual institutional change is becoming a central focus of explanation in social sciences (Mahoney \& Thelen, 2010a). Principally, this is being used to explain how institutions change gradually over time basing on enabling circumstances. Three factors explain institutional change namely features of the political context, characteristics of the institutions, and the type of dominant agents (Mahoney \& Thelen, 2010b). The power dynamics for instance who wields more power and authority has a bearing on how institutions change and the direction, and characteristics of such a change. Institutional characteristics relate to the discretion in applying the rules underlying the institutions or enforcing these rules (ibid.). Lastly, change agents are the actors behind institutional change.

\subsection{Citizen participation and civil society engagement}

The notion of citizen participation in governance has changed over time. Literature on citizen's participation is diverse, with Cornwall (2004) pointing to 'invited spaces' of participation with questions of 'who is invited', for what reasons, by who and how as key. Principally, this leads to inclusion, and exclusion of some stakeholders. Further, this has been disaggregated into 'issue-based defined citizenry' which is dynamic and overlapping and 'the people defined citizenry' which is static and geographic (Hendricks, 2010; Warren, 2008). In practice, the application of these approaches yields different results as one is focused on issues and the other on a defined location. Despite this, there is a growing citizenship literature arguing for the poor to opt out of participatory governance and focus on alternative non-state related channels (Robins, Cornwall, \& Lieres von, 2008; Thompson, 2007). This body of literature is informed by the disillusionment of participatory approaches through formal spaces (Edwards \& Gaventa, 2004, 2005).

Alternatively, this point to citizen participation anchored on civil society engagement. Civil society at the local level with context specific needs, better defined issues, and strategies including the chronically poor, and marginalised leads to the creation of better citizens who would then be able to contribute to social, political 
and economic development (Cornwall \& Coelho, 2006: 6; Thompson, 2007). For instance, in Cape Town's largest informal settlement (Khayelitsha), community participation imbued in civil society formations cultivated a particular kind of local leadership, and accountability mechanisms built on direct engagement with city leadership (Piper, 2012: 17). Further, key lessons from community participation through civil society-municipal engagement points to how power relations influence governance processes, and the importance of building participatory urban governance that facilitates the ability of urban populations to collectively, and effectively respond to challenges affecting their everyday life (Aylett, 2010).

\subsection{Slum upgrading}

The challenge of slums in global south cities is well pronounced. In fact, slums have become 'part of the sum and substance of cities in the south' (Milbert, 2010: 300). Responses to the slum challenge have ranged from demolition, and resettlement to formalisation of the informal (Weksea, Steyn, \& Otieno, 2011; Wirlin, 2010). Current practice favours slum upgrading to improve settlement conditions (services such as water, sanitation, tenure security, roads) with little or minimal displacement of residents. Literature points to the failure to ensure that governance arrangements can sustain, and upscale slum upgrading interventions (Minnery et al., 2013: 162; Van Horen, 2004). Minnery et al. (2013) convincingly contends that the most useful approach to slum upgrading entails changes in urban governance in which community capital can be maintained, and improved over the long term. Such an approach goes beyond basic services provision as it entails changes in governance cultures.

\section{Housing the urban poor in Zimbabwe}

Slum dwellers in Zimbabwean cities and Harare in particular have a history of evictions with the Government and city councils failing to adopt inclusive and sustainable solutions. For instance, informal settlers were evicted from Mbare and Epworth during the preparations to host the Commonwealth Heads of Government Meeting in 1991 (Auret, 1995). The Queen of England, and other Heads of States were coming to Zimbabwe, and slum dwellers were evicted and 'hidden' in holding camps far away from the city centre, and main transport routes. Most settlers were relocated to Churu Farm and Dzivarasekwa Extension. When liberation war icon Ndabaningi Sithole took over Churu farm, and wanted to house evicted people, government relocated them to Hatcliffe Extension and later moved some to Caledonia, and finally Hopely in 2005 during Operation Garikai (government led housing programme after Operation Restore Order) (Cf. Chitekwe-Biti, 2009). Such politicisation of informal settlements makes it difficult to provide long lasting urban planning solutions. In 1991, informal settlers from Mbare, and Epworth were evicted to Porta Farm, and were subsequently moved to Dzivarasekwa Extension, and Hatcliffe (Auret, 1995). Those who were moved to Dzivarasekwa Extension (where there were cabins with demarcated stands), were relocated to Hatcliffe Extension (settlers were given housing stands with leases by the Ministry of Local Government) in 2002. In 2004, people had built temporary structures in Hatcliffe Extension, and Operation Restore Order, launched a year later, destroyed those structures despite people being in the comfort of their leases. During Operation Restore Order, most people were relocated to Caledonia holding camp. At the same time, Hopley became a settlement of people evicted from Caledonia, Porta farm and Hatcliffe Extension until today.

The housing challenge became more prominent during and after the infamous Operation Murambatsvina/Restore Order of 2005.
Operation Restore Order is a house demolition campaign launched by the Government of Zimbabwe in May 2005. The Operation destroyed houses or structures which were considered illegal by planning law and regulations. Armed with a council plan, the police began setting alight brick houses when their owners protested that they had paid for, and been given the stands and building rights by the council, the police said they had been illegally issued by corrupt officials and had to be demolished (Action Aid International, 2005: 20). According to the United Nations Special Envoy Report, the Operation left more than 700,000 households homeless, and affected a further 2,4 million (Tibaijuka, 2005).

Urban housing for the poor is entangled in bigger national political struggles and dynamics. With time, it emerged that Operation Restore Order political motivations were bigger than planning motivations. Bratton and Masunungure (2006: 21) posit that one of the aims of the Operation was "to stifle independent ... political activity in the country's urban areas". Further, during the Operation, the violence was wanton, symbolic and punitive, signifying Zanu-PF's determination to maintain power and social control in the face of a population who (probably) did not provide a majority vote for it, with areas who voted for the opposition MDC the worst affected (Bracking, 2005). In essence, the Operation shows brutality of authoritarian regimes aimed at keeping their hold on power.

Bowing to international condemnation and pressure, the Government of Zimbabwe launched Operation Garikai. Operation Garikai was a government housing program spearheaded by the Zimbabwe National Army in the aftermath of Operation Murambatsvina/Restore Order. Government participation in actual land servicing, and house construction was through the flagship Operation Garikai/Hlalani Kuhle, which however has remained a modest contribution to addressing housing shortages in Zimbabwe (Chatiza \& Mlalazi, 2009). The programme provided housing units and stands without offsite infrastructure, and latter handed over to urban councils. However, urban councils are contesting the forced handover arguing that is equivalent to 'dumping' a chaotic programme.

\section{Housing institutions and actors}

Main institutions involved in housing delivery include central government, local authorities, private sector, building material suppliers, financial institutions, construction sector, and civil society organizations. Their main functions include land allocation, land use planning, and land policy (central government); land allocation, land use planning and offsite servicing (local authorities); land development and servicing (private sector); provision of finance to home builder and land development (financial institutions) and savings and social mobilization (civil society) (Chatiza \& Mlalazi, 2009).

Over the years the capacity of these institutions to provide housing for the urban poor has been shrinking drastically. In particular, local authorities are hamstrung to deliver the extent of the housing need. This constrain is explained by land availability, housing delivery approaches, and economic challenges. In general, land for low-cost housing is lagging behind. Shortage of land for low-cost housing in cities is evidenced by 62 slums in the city of Harare (Dialogue on Shelter, City of Harare, \& Zimbabwe Homeless Peoples Federation, 2014); as most local authorities lack legally developed land suitable for the development of low-cost housing (UNHABITAT, 2006).

Further post-2000, the urban land question became topical than ever in Zimbabwean history, as social movements (community based organisations and housing cooperatives) challenged the conventional way of housing provision. The conventional way of housing provision is through local authorities allocating housing land or actual housing 
units to individuals on the housing waiting list. Housing cooperatives went beyond housing provision struggles to include land reclamation and challenging housing provision institutional arrangements (Masuko, 2008). Some housing cooperatives were aligned to the ruling party, Zanu-PF, and most MDC controlled local authorities refused to accept these cooperatives arguing they were 'part of an illegal housing and urban planning system'.

Despite political contestations, cooperatives have made significant progress in acquiring land from urban local authorities. For the year 2011, the City of Harare allocated 2954 residential stands to 76 housing cooperatives and 16 individuals on the housing waiting list (in excess of 500,000 home seekers) (CoH DHCS, 2012). During the same year, the city trained and registered 243 housing cooperatives with a total membership of 15,311. Between 2000 and 2012 the City of Harare allocated 12,554 housing stands to 254 housing cooperatives with 2301 housing units completed. ${ }^{1}$ Despite this, most housing cooperatives are struggling with qualitative dimensions of housing such as water, sanitation and roads infrastructure. The initial investment in such infrastructure is beyond the reach of many cooperatives.

At the same time, the City of Harare has been partnering private companies in delivering housing. These include Central African Building Society in Budiriro (5000 completed houses), Infrastructure Development Bank of Zimbabwe (72 completed housing units), Shelter Zimbabwe (6-7000 stands), Pearl Properties (flat block with 132 units), and Glaudina (1351 stands) (CoH DHCS, 2012). However, the above-named projects are for medium to high income residents with stringent access conditions such as bank accounts and some form of collateral making them inaccessible to the urban poor.

The alliance between the Zimbabwe Homeless People's Federation (herein after the Federation) and Dialogue on Shelter have made the largest contribution to low-cost housing for the urban poor in Zimbabwe. The Federation is a community based organization which emerged in the two holding camps of Hatcliffe Extension and Dzivarasekwa Extension. The organisation was formed in 1998 and its main aim is facilitating housing access to the urban poor through challenging conventional housing delivery methods and providing alternative methods. The conventional method prioritises the housing waiting list as the basis for land and housing allocation by local authorities. As of 2014, the Federation had a membership of more than 55,000 households and had facilitated access to housing stands to 15,000 households in Zimbabwe's 52 local authorities.

Founded in 1998, Dialogue on Shelter is a Zimbabwean nongovernmental organisation that provides technical support to the Zimbabwe Homeless People's Federation. The alliance between the Federation and Dialogue on Shelter is the largest social movement in Zimbabwe advocating for housing access to the urban poor. Through intense negotiations with central government, the alliance has managed complex relationships, built a collective coherent voice across its membership, built and manages alliances with other organisations working towards the same goals and constructively engages with government on a set of very tangible outcomes (Chitekwe-Biti, 2009: 366).

\section{Research methodology}

The objective of this research is to investigate how the Harare slum upgrading programme is promoting inclusive municipal governance. Data for this article was gathered from the City of Harare, project beneficiaries in Dzivarasekwa Extension,

\footnotetext{
1 Statistics collated form the City of Harare Housing Cooperatives Register.
}

Federation coordinators and Dialogue on Shelter project officers. ${ }^{2}$ These interviewees were selected purposively since they are involved in the slum upgrading programme on a day to day basis. Focus group discussions were held with Federation coordinators and project beneficiaries focusing on changes in community-city engagement, project impact, and planning and delivery of services. Key informant interviews were conducted with City of Harare and Dialogue on Shelter officers and were premised on experiences with the project, changes over time and impacts in terms of inclusiveness of Harare City and opportunities that remain available to impact inclusive governance. Key informants had expertise in community mobilisation, housing (slum upgrading in particular), municipal governance and urban planning. Further, case profiles focusing on individual beneficiaries as the units of analysis in relation to access to housing were conducted. In addition, the research made use of extensive grey project literature such as project documents (work orders, monthly, quarterly and annual narrative reports, and memorandum of agreements) and project outputs such as slum upgrading strategy, enumeration and profiling reports. Key research questions which guided the research are:

a) How is slum upgrading promoting inclusive municipal governance?

b) What urban governance and urban planning changes have occurred within the City of Harare?

c) What is the impact of slum upgrading on beneficiaries' lives?

d) What policy implications are emerging from slum upgrading experience?

\section{Slum upgrading in Harare}

The Harare Slum Upgrading programme is supported under the Bill and Melinda Gates Foundation's Global Programme for Inclusive Municipal Governance which is being implemented in five African cities namely Cairo, Harare, Lilongwe, Luanda and Monrovia. The purpose of the global programme is to create and strengthen municipal and community partnerships to tackle city challenges in an inclusive manner. In Harare, the 5 year (2010-15) programme is implemented through the partnership of City of Harare, Dialogue on Shelter, and Zimbabwe Homeless Peoples Federation. ${ }^{3}$ To define programme, and partnership parameters, the partners are bound by a Memorandum of Agreement.

Harare, as a city has been facing serious political and economic challenges for decades. The drastic sharp increase in urban poverty and destitution in Harare after the Economic Structural Adjustment Programme has been alluded to (Kanji, 1995; Potts \& Mutambirwa, 1998). The socio-economic and political crisis beginning 2000 exacerbated the lives of the urban poor. In particular, two things were prominent. One is the deindustrialisation of Harare, as foreign capital relocated to neighbouring countries due to high fiduciary risks and harsh economic environment in Zimbabwe. Second is the political contestation for the control of Harare city between MDC

\footnotetext{
2 Three officers from Dialogue on Shelter and three from the City of Harare Housing and Urban Planning departments, and 50 project beneficiaries.

3 The objectives of the programme are to conduct a basic situational analysis of all settlements with inadequate shelter and services in Harare; select at least one settlement for the implementation of a more detailed needs assessment; create an action plan to address priority needs with funding from the Gates Foundation as well as City of Harare and community resources; mobilise additional funding to further resource the action plan; document and disseminate lessons learnt from the experience through reports, videos, photographs and exchange visits; and create a work plan to replicate the process in other disadvantaged settlements in Harare.
} 


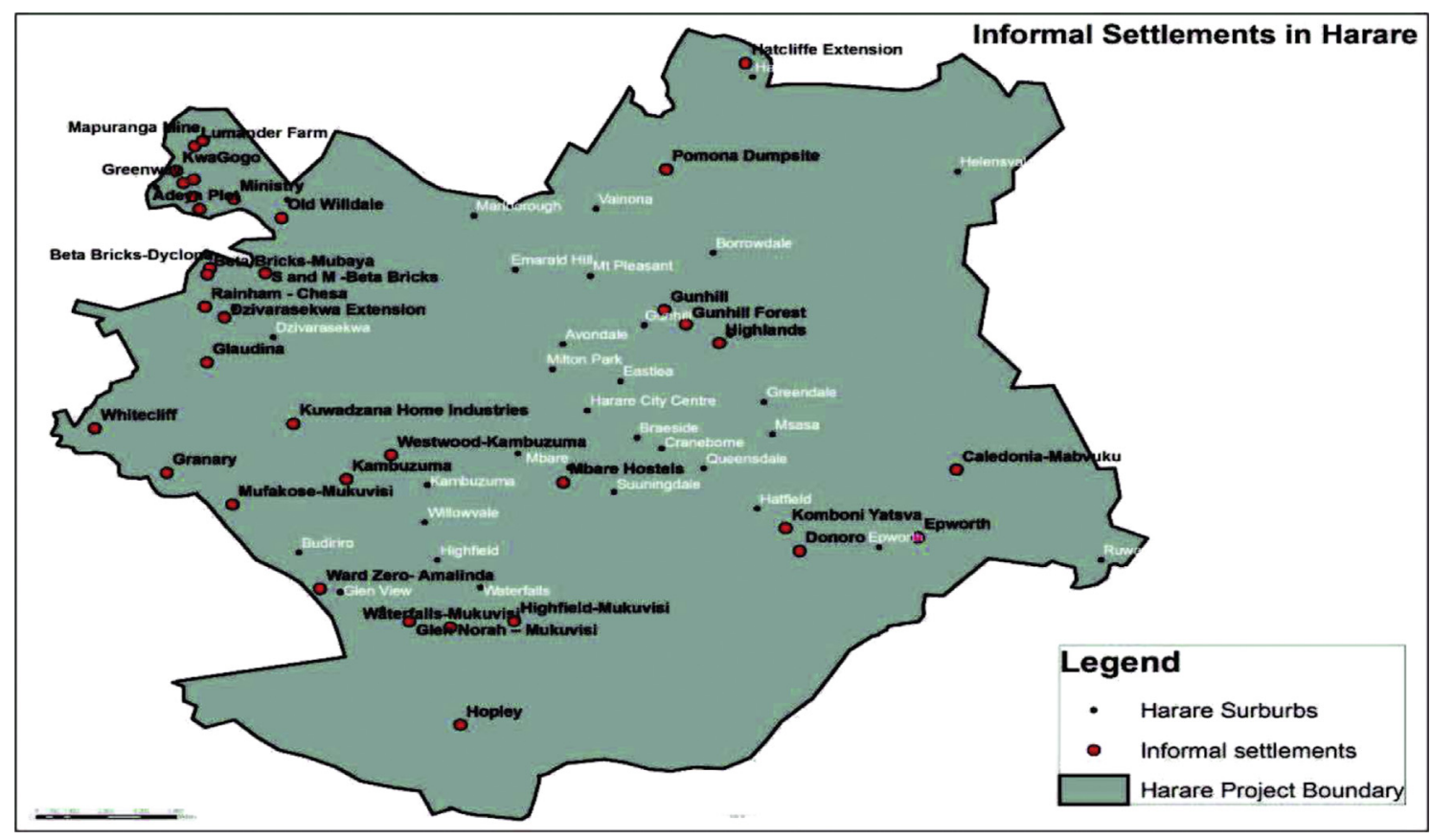

Fig. 1. Map showing informal settlements in Harare (Source, Dialogue on Shelter et al., 2014).

and Zanu-PF, which led to the latter radically intervening in urban affairs (Kamete, 2006; McGregor, 2013; Ranger, 2007). For civil society and non-governmental organisations, state repression at local government level and contentious politics make it difficult to engage, protect and promote the rights and interests of residents (Kamete, 2009). This context affected the governance of the city and its ability to perform functions.

The slum upgrading site (Dzivarasekwa Extension) is shown on Fig 1 as well as informal and planned settlements in Harare.

\section{Research findings and discussion}

\subsection{Emergence of municipal-community partnership}

Considering the anti-slum history of the Zimbabwe government and city of Harare, acceptance by the two of slum upgrading was triggered by a number of engagement processes. First, are the exchange visits facilitated by Dialogue on Shelter, and the Federation which enlightened city and government officials on the efficacy of slum upgrading in other countries such as India, South Africa, and Kenya. Since 1998, the alliance of Dialogue on Shelter and the Federation rose to become a prominent movement advocating for pro-poor housing in Zimbabwe's urban and rural centres. The alliance has navigated a harsh economic and political environment creating new solutions for housing and livelihood strategies (Chitekwe-Biti, 2009). Second, is the enduring change that the city embraced through working with civil society and community groups. Of particular to note is the 'open door policy' of the Mayor of Harare who actively engaged with the Federation, Gates Foundation, city and government officials from the initial discussions on slum upgrading. The mayor was instrumental in convincing central government about participating in such a programme. Third, the government led National Housing Convention revealed the essence of prioritising community based organisations in pro-poor housing delivery (GoZ, 2009). Fourth, the Harare Partnership underwent a consensus building process which facilitated shared meaning and understanding of slum characteristics and action points.
The inclusive process of developing the National Housing Policy assisted the Harare Partnership. The National Housing Policy recognised the Zimbabwe Homeless Peoples' Federation and Dialogue on Shelter for the first time as institutions involved in urban poor housing. Further, the policy adopted incremental development, ${ }^{4}$ a 'no eviction without alternative' principle, and people-centred housing development (GoZ, 2012). The Government recognised the importance of slum upgrading and civil society participation in housing development. Perhaps, the Harare slum upgrading provided the first practical approach to dealing with slums and at the same time promoting inclusive municipal governance. Further, the new Constitution of Zimbabwe has provisions that advance the rights of the homeless and these relate to Sections 28 (Shelter), 74 (freedom from arbitrary eviction) and 77 (right to food and water) (GoZ, 2013). From the foregoing, slum upgrading was facilitated by engagement strategies, and processes (initiated mainly by Dialogue on Shelter and the Federation) and contextual factors such as the National Housing Convention, new Housing Policy, and new Constitution. The main actors in the slum upgrading programme are City of Harare, central Government, Dialogue on Shelter, Zimbabwe Homeless Peoples Federation, Gates Foundation, University of Zimbabwe, and other local authorities. In summary, Table 1 shows these actors and their roles in slum upgrading.

\subsection{Slum upgrading institutional structure}

Slum upgrading in Harare is steered by a Project Management Committee composed of four representatives from City of Harare, ${ }^{5}$ two from Dialogue on Shelter and two from the Federation. The committee co-opts relevant council departments based on year

\footnotetext{
${ }^{4}$ Defined by the Zimbabwean Government as a 'housing development strategy which allows the developer to start constructing essential services such as water and sanitation and allow beneficiaries to occupy their stands. Other services such as electricity and street lighting can be constructed later when funds are available'.

${ }^{5}$ From four departments namely Housing and Community Services, Chamber Secretary, Engineering and Urban Planning.
} 
Table 1

Slum upgrading actors and roles.

\begin{tabular}{|c|c|}
\hline Lead actor/s & Roles \\
\hline Government & Land allocation \\
\hline City of Harare & $\begin{array}{l}\text { Approving plans, infrastructure development, developing \& implementing a Slum Upgrading Strategy, providing } \\
\text { land tenure permits, reviewing of planning regulations and approval processes, co-managing the programme, } \\
\text { mobilising additional finance for replicating slum upgrading. }\end{array}$ \\
\hline Dialogue on Shelter & $\begin{array}{l}\text { House Modelling, managing community savings and credits, slum Upgrading Finance Facility Study, } \\
\text { documentation and dissemination of slum upgrading, profiling and enumeration, co-managing the programme, } \\
\text { mobilising additional finance for replicating slum upgrading. }\end{array}$ \\
\hline The federation & $\begin{array}{l}\text { Community mobilisation and organisation, participation in infrastructure provision, documentation and } \\
\text { dissemination of slum upgrading, profiling and enumeration, savings mobilisation, co-managing the programme, } \\
\text { mobilising additional finance for replicating slum upgrading. }\end{array}$ \\
\hline University of Zimbabwe & Participatory urban planning and development. \\
\hline $\begin{array}{l}\text { Other local authorities (Bulawayo, Chinhoyi, Kariba, } \\
\text { Kadoma, Masvingo \& Epworth) }\end{array}$ & Learning partners for sharing slum upgrading lessons, replicating slum upgrading. \\
\hline Gates foundation & Financing slum upgrading, general programme oversight. \\
\hline
\end{tabular}

Source: Research Findings, 2014.

plans and activities, an indicator of flexibility. Roles of the project management committee include project reporting, managing the project and developing work plans. The project management committee operates at both project and city level primarily bridging the gap between city authorities, and the urban poor. The Federation members have direct representation in the committee and have used this mechanism as a platform to raise their concerns. Slum dwellers understanding of city governance has improved as the urban poor are taking ownership and responsibility of city programmes; an indication of being part of city governance. Sharing, and comparing notes on urban poor housing has demystified the conception that the poor are only recipients of urban development processes.

The major challenges and disputes arising from the project management committee have been interdepartmental coordination within City of Harare, and adherence to planning standards. This, in addition to bureaucratic internal controls, and procedures is constraining city-community engagement processes. Slum upgrading is a new phenomenon to the city, with city professionals not directly involved in the programme showing resistance. Commenting on this, the Housing and Community Services Directorate argued that 'unless this (slum upgrading) is a very successful project and well documented, the resistance within council will still be prevalent'. On analysis, the slum upgrading programme requires investment in development communication that is documentation and dissemination of project information, and lessons learnt. This assists in a 'relearning' exercise in which council officials appreciate the importance of slum upgrading and its currency in housing.

Generally, the project management committee has been effective but its impact in Council processes is faint. This is explained by three factors. First is that, a Technical Advisor envisaged for the Mayor (linking with the project management committee) was not recruited. Second, the City of Harare housing policy is yet to be revised to incorporate lessons from the project. Codifying slum upgrading lessons through a revised City of Harare housing policy is critical for sustaining slum upgrading lessons. The efficacy of using the project management committee to steer reflection and capacity building within the Harare Partnership is unconvincing. Rather, a slum upgrading unit can provide a sustainable and effective framework for institutionalising slum upgrading policy and practice. In addition, such a unit can be an agent for replication, and upscaling of slum upgrading.

\subsection{Political contestation}

The programme initially earmarked Mbare; the first African township built in 1907 and situated $3 \mathrm{~km}$ south of the city centre
(Zinyama, Tevera, \& Cumming, 1993). For the project outputs in Mbare, the ruling party, Zanu-PF through its vigilante group Chipangano claimed $51 \%$ of the housing units, as part of the government's indigenisation and empowerment programme. The conception from Zanu-PF was that the programme was funded by foreign capital (Gates Foundation) hence the need for the party to claim ownership of the majority of project outputs. Due to political contestation in Mbare, the project was moved to Dzivarasekwa Extension. Dzivarasekwa Extension was established as a holding camp for evicted settlers within Harare in early 1990s. In 2006, the Government of Zimbabwe allocated land to the Federation though the latter's members and other people had been living at the site informally since 1991 .

Changing the project from a political hotspot to Dzivarasekwa Extension had an effect of neutralising Zanu-PF. Management of the relocation process was not politicised. Moreover, the Federation is apolitical; one of the rituals the organisation has managed to uphold during slum upgrading. In Dzivarasekwa Extension, there are no Zanu-PF vigilante groups, and in successive elections, it has been an opposition stronghold. Further, as alluded above the land where the project was relocated to had been allocated to the Federation by the local government ministry in 2006. These factors helped in muting urban political dynamics in Dzivarasekwa Extension. Slum settlements in Zanu-PF strongholds pose high risks of political dynamics and contestation. Such settlements are even difficult to carry out processes such as enumeration, and profiling. This is mainly because the party does not want 'outsiders' to be in control of any development process. Working in such settlements requires impartiality, and depoliticisation firmly supported by the local community.

\subsection{Profiling and enumeration}

The Harare Partnership agreed that slums were a reality in Harare hence the need to document lived realities in slums. The slum profiling exercise follows an iterative process of identification, sensitisation, profiling, enumeration, documentation and feedback (Dialogue on Shelter et al., 2014: 5). In general this is similar to conventional processes of profiling, enumeration and mapping prevalent in many countries (Cf. Patel \& Baptist, 2012). Slum profiling and enumeration is providing the urban poor with an opportunity to meaningfully contribute to informed decision making by city officials. Moreover, profiling and enumeration reflects recognition of slum dwellers, and their settlements by city authorities and thus the beginning of making the urban poor part of overall municipal governance. A total of 62 slum settlements with an estimated 37,936 households and approximately 165,609 people 
were profiled (Dialogue on Shelter et al., 2014). The participation of the City of Harare in city-wide profiling, and enumerations led to the understanding by the city council of urban poor concerns, and the geography, spatial and socio-economic characteristics of slums.

However, the profiles do not capture community aspirations in relations to livelihoods, and an all-inclusive urban development agenda. Equally missing also is an opportunity to milestone the whole profiling, and enumeration as city-community transformation, and capacity building tools. Principally, the understanding of the reality of slums is not made sufficiently critical, and action-oriented within the framework of slum upgrading. In this case, profiling, and enumerations are reduced to a ritual with limited impact on community, city and national level decision making and implementation. Alternatively, future profiling, and enumeration should be packaged in a way that triggers action on the part of city authorities.

\subsection{Participatory urban planning and development}

Community-city engagement is through planning, and development of infrastructure. In particular, communities contribute their imaginations with regards to the form and structure of the settlement they want. Harnessing community input in urban planning is practiced through informal planning studios. Participatory informal Planning Studios are carried out through a cooperation among the University of Zimbabwe's Planning School, City of Harare and slum dwellers. Informal planning studios allow slum dwellers to reflect on their settlement challenges and map possible solutions leading to Development Plans. Further, from pegging, engineering designs, and road construction, communities actively participate in these processes. The community provides labour during infrastructure works for instance laying of water, and sewer pipes, and building houses. There have been extensive consultations and participation of the urban poor in the 16 model houses, and reduction of construction costs for a $24 \mathrm{~m}^{2}$ two roomed house to US\$2400.

However, the debate on densification remains inconclusive regarding space for structures and open land, multi-storey construction and Council standards. The main challenges are to do with densification, as people have not embraced the concept. This is partly due to cultural resistance, and costs associated with densification. Further, most informal dwellers often settle on private land, making it difficult to agree on formalisation and regularisation. In most instances, city authorities show a resentment attitude on such informal settlements. Nevertheless, such settlements can be dealt with through providing communal services whilst waiting for relocation to council designated land.

\section{Impacts}

\subsection{Review of planning regulations}

Zimbabwe's town planning standards have been castigated as 'very high, very elaborate, rigid and not amenable to physical and climatic conditions', irresponsive to end users with planners criticised for planning for themselves (GoZ, 2009). Town planning standards, Model Building Bye-Laws, planning legislation, infrastructure standards and plan preparation and approval processes have been singled out as key deterrents to the provision of low cost housing (Mhashu, 2009). The result of such planning indicators has been a housing sector characterised by inadequate affordable and decent housing, low level of urban home ownership and inappropriate dwelling units (GoZ, 2011). To remove such bottlenecks in housing delivery, the Harare slum upgrading advocated for a review of planning regulations and plan approval process focusing on public and stakeholder participation, inclusive capacity development, densification, housing technology research and experimentation (City of Harare, Dialogue on Shelter Trust \& Zimbabwe Homeless People's Federation, 2012). However, such shifts require structural changes within the City of Harare and tapping political will at central government level (especially Ministry of Local Government, Public Works and National Housing). These changes are a process over time, and can be done incrementally for instance though implementing pilot projects using reviewed planning regulations. Further, exposure visits can catalyse shifts in attitudes, at the same time linking practical pilots to policy review.

\subsection{Living in slums without fear}

Many slum dwellers are victims of the infamous Operation Murambatsvina/Restore Order. Prior to the Harare Slum Upgrading programme, slum dwellers in Harare lived in constant fear. Shacks in slums were regularly burnt such that slum dwellers resorted to cheaper and portable materials such as cardboard boxes. Fearing authorities, slum dwellers would hide their convertible shacks during the day and rebuild the shacks in the evening. Such was the painful life of slum dwellers in Harare. However, the slum upgrading programme brought renewed hope, providing slum dwellers with essential services (water, sanitation, roads and tenure security). In particular, slum dwellers now live peacefully as part of the urban fabric with hopes of owning permanent houses one day. City authorities, and slum dwellers host planning meetings together in these slums; a development that was unusual before. Through informal planning studios, slum dwellers are envisioning their settlements contributing to development plans.

\subsection{House/land ownership, new beginnings}

In Zimbabwean cities, owning a house or housing stand is a nightmare to the majority of the urban population. The slum upgrading programme benefited 480 poor households who are now landlords with sectional (249) and individual (231) titles. This is a new beginning as house ownership benefits accrue. For instance the social status of these households has improved among family members and society at large. The 2012 Dzivarasekwa Extension enumeration revealed that there were 121 plastic shacks, 76 grass-thatched shacks, 70 shallow unprotected wells, 18 deep protected wells, 1 borehole, and 88 pit latrines and insecure tenure (ZIHOPFE, City of Harare \& Dialogue on Shelter, 2012). At present, slum dwellers are living in a planned settlement, with reticulated water and sewer and road infrastructure. Such services mean a new beginning for the community. From shallow wells to reticulated water signals the new living conditions of slum dwellers. For sanitation, the transition from pit latrines and sky-loos to reticulated sewer shows community transformation. However, such transformation means a new responsibility of paying water bills and tariffs to the city council. Some beneficiaries are struggling to pay municipal bills (water and sewer) which have accrued to over US $\$ 100$ per household. This indicates to the importance of including livelihood diversification means in slum upgrading. Such an approach helps in increasing the disposable incomes of the poor, which allows them to fulfil their obligations to the municipality.

\subsection{Expansive pool of beneficiaries}

The project's direct beneficiaries are the 480 families settled in Dzivarasekwa Extension, 37,456 households in the 62 slums profiled, the 52,000 Federation members and other slum dwellers whose capacities have been built and whose socio-economic and political security has been partially boosted through participation 
in the slum upgrading programme. Using a national average household size of 4,2 (ZIMSTAT, 2012) means 2016 people benefited directly through accessing tenure, water, sewer and road infrastructure. The populations of other urban centres (Epworth, Kadoma, Masvingo, Kariba, Chinhoyi and Bulawayo) benefited directly and indirectly as their councils adopted and practised incremental development in addressing slum challenges.

Fellow Federation members selected beneficiaries using selection criteria including resident area, savings, community and Federation relations, livelihood means and lifestyle. Comparatively, overall participation, and commitment to Federation principles and the project contributed to housing access. Vulnerability such as health and income status, Orphans and Vulnerable Children were also considered providing for a broad and inclusive selection process through which deserving beneficiaries were selected. There were 152 families residing at the settlement, and they were nonfederation members. However, these people are beneficiaries, showing inclusion of the upgrading process. Allocation of sectional and individual title was through a consensus to allow those 'original settlers' to maintain their social capital. Individual allocation of stands was through a lottery; a method of ensuring transparency.

\subsection{Resilience of the urban poor}

Through providing security of tenure, infrastructure services (water, sanitation, roads and storm drains) and increasing access to critical spaces for engaging with city authorities, the Harare Partnership contributes to the resilience of the urban poor. The socioeconomic characteristics, and livelihoods of the project beneficiaries are often precarious and benefiting from this project is an important step in building the resilience of urban poor livelihoods. Community participation led to the transfer of skills to the local community. Specifically, the community acquired skills in infrastructure installation such as laying of water and sewer pipes, building among others which they are using elsewhere as livelihoods means. The builders trained by City of Harare builders are building model houses for the project and also having their own construction entities earning them a living. Dzivarasekwa Extension is an area susceptible to flooding; however the installation of infrastructure services is becoming key in reducing the vulnerability of the poor and strengthening community safety and resilience.

Slum Upgrading Story: From a flooded shack to a model house (Pictures courtesy of George Masimba-Nyama, Dialogue on Shelter).

\section{Conclusion}

Inclusive municipal governance in Harare was triggered and supported by both internal and external factors. Previous and present technical competencies and experiences of Dialogue on Shelter and the Zimbabwe Homeless Peoples Federation facilitated municipal-community engagement. Influences of the Gates Foundation and the Mayor of Harare were equally critical in promoting City acceptance to such an initiative. Generally the Inclusive Government provided an enabling political environment for slum upgrading. The Government led National Housing Convention set the road map for a pro-poor and inclusive housing delivery agenda. The new Constitution and National Housing Policy pronounced the importance of inclusive governance premised on citizen participation. Participatory urban planning and development, profiling and enumeration are important inclusive municipal governance processes. However for sustainability at city-wide level, these processes require active City participation and extensive knowledge sharing and dissemination. Addressing concerns of the poor is susceptible to political risks, requiring strong impartiality to counter such forces. The impacts of Harare slum upgrading are multi-layered: for instance city review of planning procedures and applying lessons to other projects; noticeable changes in relations between the city and slum dwellers; improvements in the socioeconomic status of slum dwellers; and other cities are learning from the Harare Partnership. For institutional arrangements, the Harare experience points to the necessity of a Slum Upgrading Unit; as a focal point for leading, documenting, implementing, monitoring and evaluating slum upgrading.

Further research is needed to assess the readiness of main housing institutions to replicate and upscale slum upgrading nationwide. Such an assessment should target both state and nonstate actors. Principally, this helps in addressing bottlenecks affecting the recognition and development of slum areas. Moving forward, the Harare Partnership requires a lessons learnt exercise in which partners introspect. Such introspection informs new strategies critical in replicating and upscaling slum upgrading at both city-wide and national level.

Basing on evidence from the Harare Slum Upgrading Programme, the following are critical issues for consideration in slum upgrading:

\subsection{City housing policy}

A city housing policy outlining processes, terms and conditions of slum upgrading is vital in guiding slum upgrading initiatives. A housing policy of that kind provides the parameters of engagement among different city departments. The inclusion of slum upgrading in city housing policy shows the commitment of city authorities to slum upgrading; an important feature to scalability of slum upgrading at city-wide level. Moreover, a policy compels the city to implement and practice policy proposals.

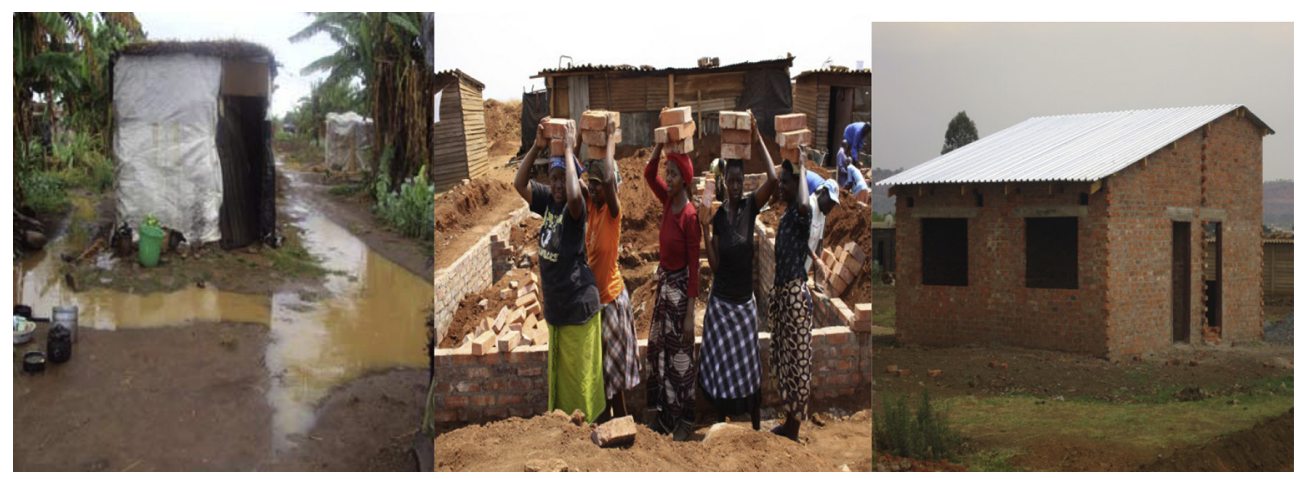




\subsection{Slum upgrading unit}

A project based approach to slum upgrading poses implementation, coordination and sustainability challenges. A slum upgrading unit can provide a sustainable and effective framework for institutionalising slum upgrading policy and practice. In addition, such a unit can be an agent for replication and upscaling of slum upgrading. Without a slum upgrading unit, coordination of slum upgrading is fragmented across council departments leading to unnecessary implementation delays.

\subsection{Sustainability}

Slum upgrading in Harare utilises free resources such as land, gravel, water and labour from the city of Harare and labour contribution by the targeted slum dwellers. If such resources are provided at a cost, this casts doubt on affordability by the urban poor considering also the infrastructure costs to be incurred. In terms of project efficiency such a model can be unsustainable, making it difficult for city authorities to replicate slum upgrading city-wide.

Perhaps, this indicates to the need to go for low capital intensive infrastructure when providing urban services to the poor. However, for Harare, the opposite is true, infrastructure is very expansive, costly and of high quality providing challenges of maintenance by the urban poor. In this regard, slum upgrading created an 'island' of well-planned and expansively built infrastructure. Without another grant, the City of Harare and its partners will not be able to replicate slum upgrading using the Dzivarasekwa Extension model.

\section{Acknowledgements}

I would like to thank two anonymous reviewers, the editor, and George Masimba-Nyama for their comments which enriched this article. Worth mentioning also are the countless informal discussions with Molin K. Chakamba and Enara Jasi; which invariably assisted the development of this paper.

\section{References}

Action Aid International. (2005). Burning down the house to kill a rat! an analysis of the demolitions in Zimbabwe. Johannesburg: Action Aid International.

Auret, D. (1995). Urban housing: A national crisis. Gweru: Mambo Press.

Aylett, A. (2010). Conflict, collaboration and climate change: participatory democracy and urban environmental struggles in Durban, South Africa. International Journal of Urban and Regional Research, 34(3), 478-495.

Bracking, S. (2005). Development denied: autocratic militarism in post-election Zimbabwe. Review of African Political Economy, 32(104/105), 341-357.

Bratton, M., \& Masunungure, E. (2006). Popular reactions to state repression: operation murambatsvina in Zimbabwe. African Affairs, 106(422), 21-45.

Campbell, J. L. (2009). Institutional reproduction and change. In G. Morgan, J. Campbell, C. Crouch, O. K. Pedersen, \& R. Whitley (Eds.), The oxford handbook of comparative institutional analysis (pp. 87-116). Oxford: Oxford University Press.

Chatiza, K., \& Mlalazi, A. (2009). Human settlement needs assessment in Zimbabwe: Critical review and proposed methodology. Harare: UNHABITAT and Government of Zimbabwe.

Chitekwe-Biti, B. (2009). Struggles for urban land by the Zimbabwe homeless people's federation. Environment and Urbanization, 21(2), 347-366.

City of Harare, Dialogue on Shelter Trust, \& Zimbabwe Homeless People's Federation. (2012). Harare slum upgrading project: Review of planning regulations and plan approval processes in the city of Harare. Harare: City of Harare.

$\mathrm{CoH}$ DHCS (City Of Harare Department of Housing and Community Services). (2012). Department of housing and community services annual report 2011. Harare: City of Harare.

Cornwall, A. (2004). New democratic spaces? The politics and dynamics of institutionalised participation. IDS Bulletin, 35, 1-10.

Cornwall, A., \& Coelho, V. S. (2006). Spaces for change? The politics of citizen participation in new democratic arenas. London: Zed Books.
Dialogue on Shelter, City of Harare, \& Zimbabwe Homeless Peoples Federation. (March 2014). Harare slum upgrading profile report (2nd ed.). Harare: Dialogue on Shelter and City of Harare.

Edwards, M., \& Gaventa, J. (2004). Global citizen action. Boulder: Lynne Rienner. Gaventa, J. (2001). Participatory local governance: Six propositions for development IDS, paper presented to the ford foundation, LOGO program officers' Retreat, June. Gaventa, J. (2005). Seeing like a citizen: Reclaiming citizenship in a neo-liberal world. Citizenship DRC synthesis paper, November.

Gaventa, J. (2007). Participation and citizenship: Exploring power for change. Presentation at 'development horizons: Future directions for research and policy' series. London: IDS/IIED/ODI, 22 January 2007.

GoZ (Government of Zimbabwe). (2009). Second national housing convention report. 29-30 October 2009, elephant hills hotel, victoria falls. Harare: Ministry of National Housing and Social Amenities.

GoZ (Government of Zimbabwe). (2011). Medium term plan (2011-15). Harare: Printflow.

GoZ (Government of Zimbabwe). (2012). National housing policy 2012. Harare: Ministry of National Housing and Social Amenities.

GoZ (Government of Zimbabwe). (2013). Constitution of Zimbabwe Amendment (No. 20), Act, 2013. Harare: Government Printers.

Hendricks, B. (2010). City-wide governance networks in Nairobi: towards contributions to political rights, influence and service delivery for poor and middleclass citizens? Habitat International, 34, 59-77.

Hyden, G., Court, J., \& Mease, K. (2004). Making sense of governance: Empirical evidence from sixteen developing countries. Boulder, Co: Lynne Rienner.

Kamete, A. Y. (2002). Governing the poor in Harare, Zimbabwe: Shifting perceptions and changing responses. Research report No. 122. Uppsala: Nordic Africa Institute.

Kamete, A. Y. (2006). The return of the jettisoned: ZANU-PF's crack at 're-urbanizing' in Harare. Journal of Southern African Studies, 32(2), 255-271. Jun., 2006.

Kamete, A. Y. (2009). For enhanced civic participation in local governance: calling tyranny to account in Harare. Environment \& Urbanization, 21(1), 59-75.

Kanji, N. (1995). Gender, poverty and economic adjustment in Harare, Zimbabwe. Environment \& Urbanization, 7(1), 37-56.

Mahoney, J., \& Thelen, K. (2010a). Explaining institutional change: Ambiguity, agency and power. New York: Cambridge University Press.

Mahoney, J., \& Thelen, K. (2010b). A theory of gradual institutional change. In J. Mahoney, \& K. Thelen (Eds.), Explaining institutional change. New York: Cambridge University Press.

Marongwe, N., Chatiza, K., \& Mukoto, S. (2011). Scoping study governance of urban land markets in Zimbabwe. Johannesburg: Urban LandMark.

Masuko, L. (2008). War veterans and the re-emergence of housing cooperatives. In S. Moyo, K. Helliker, \& T. Murisa (Eds.), Contested terrain: Land reform and civil society in contemporary Zimbabwe. Pietermaritzburg (pp. 181-206). S\&S Publishers.

McGregor, J. (2013). Surveillance and the city: patronage, power-sharing and the politics of urban control in Zimbabwe. Journal of Southern African Studies, 39(4), 783-805.

Mhashu, G. F. (2009). Address by the minister of national housing and social amenities on the second national housing convention, victoria falls, 27 October 2009.

Milbert, I. (2010). Slums, slum dwellers and multilevel governance. The European Journal of Development Research, 18(2), 299-318.

Minnery, J., Argo, T., Winarso, H., Hau, D., Veneracion, C. C., Forbes, D., et al. (2013). Slum upgrading and urban governance: case studies in three South East Asian cities. Habitat International, 39, 162-169.

Mitlin, D. (2004). Reshaping local democracy: Editorial. Environment \& Urbanization, 16(1), 3-8.

Patel, S., \& Baptist, C. (2012). Editorial: documenting the undocumented. Environment and Urbanization, 24(3), 3-12.

Pierson, P. (2004). Politics in time: History, institutions, and social analysis. Princeton: Princeton University Press.

Piper, L. (2012). Development trustees, not rent-seeking deployees: The designed meaning of community upgrading in the violence prevention through urban upgrading project, Cape Town. Working paper 11. Bellville: African Centre for Citizenship and Democracy.

Potts, D., \& Mutambirwa, C. (1998). Basics are now a luxury: perceptions of structural adjustment's impact on rural and urban areas in Zimbabwe. Environment \& Urbanization, 10(1), 55-76.

Ranger, T. O. (2007). City versus state in Zimbabwe: colonial antecedents of the current crisis. Journal of Eastern African Studies, 1(2), 161-192. July 2007: 161192

Robins, S., Cornwall, A., \& Lieres von, B. (2008). Rethinking citizenship in the 'Post colony'. Third World Quarterly, 29, 1069-1086.

Smith, H. (2004). Costa Rica's triangle of solidarity: can government-led spaces for negotiation enhance the involvement of civil society in governance? Environment \& Urbanization, 16(1), 63-78.

Sorensen, E., \& Torfing, J. (Eds.). (2007). Theories of democratic network governance. New York: Palgrave - Macmillan.

Thompson, L. (Ed.). (2007). Participatory governance? Citizens and the state in South Africa, African centre for citizenship and democracy. Bellville: University of the Western Cape.

Thompson, L., \& Tapscott, C. (2010). Citizenship and social movements: Perspectives from the global south. London \& New York: Zed Books.

Tibaijuka, K. A. (2005). Report of the fact-finding mission to Zimbabwe to assess the scope and impact of operation murambatsvina by the UN special envoy on human 
settlements issues in Zimbabwe Mrs. Anna Kajumulo tibaijuka. New York: United Nations.

UNHABITAT. (2006). UNHABITAT Zimbabwe review of activities in Zimbabwe since 2006: Towards a comprehensive and inclusive human settlement development strategy and policy. Harare: UNHABITAT Zimbabwe.

UNHABITAT. (2010). The state of African cities 2010: Governance, inequality and urban land markets. Nairobi: UNHABITAT.

Van Horen, B. (2004). Community upgrading and institutional capacity building to benefit the urban poor in Asia. Paper presented to the forum on urban infrastructure and public service delivery to the urban poor. Regional Focus: Asia, New Delhi, India.

Van der Heijden, J. (2013a). Institutional layering: a review of the use of the concept. Politics, 31(1), 9-18.

Van der Heijden, J. (2013b). A short history of studying incremental institutional change: does explaining institutional change provide any new explanations? Regulation and Governance, 4(2), 230-243.
Warren, M. E. (2008). Governance-driven democratisation: Opportunities and challenges. University of British Colombia. Essex.

Weksea, B. W., Steyn, G. S., \& Otieno, F. A. O. (2011). A review of physical and socioeconomic characteristics and intervention approaches of informal settlements. Habitat International, 35, 238-245.

Wirlin, H. H. (2010). Urban development: the importance of public administration. The Journal of Social, Political and Economic Studies, 35(4), 450-473.

ZIHOPFE, City of Harare, \& Dialogue on Shelter. (2012). Dzivarasekwa enumeration report June 2012. Harare: Zimbabwe Homeless Peoples Federation.

ZIMSTAT. (2012). Census 2012: Preliminary report. Harare: Zimbabwe National Statistics Agency.

Zinyama, L., Tevera, D., \& Cumming, S. (Eds.). (1993). Harare: The growth and problems of the city. Harare: University of Zimbabwe. 